\title{
A Proposed Cost of Books Index and Cost of Periodicals Index
}

Mr. Kurth is assistant chief, Order Division, Library of Congress.

$\mathrm{R}$ ECENT YEARS have witnessed sharp and alarming increases in the prices of books and periodicals issued throughout the world. That this trend in prices has been severe, increasingly damaging to the development of the library's book collections, and disruptive of the planning of meaningful budgetary requests, is recognized; but the precise nature of the price movement during the past fifteen years, and up to the present time, remains imperfectly known. The library administrator is thus placed at a considerable disadvantage by the lack of adequate price information. The effort to determine the changes occurring in the price of books and periodicals has been the subject, throughout various libraries, of individual price studies, which necessarily have been based on the limited and circumstantial data available, and which undoubtedly have not reflected a consistently applied statistical pattern from year to year. No convenient standard for measuring price changes, in a form satisfactorily meeting the needs of libraries, now exists. Certain data are useful, e.g., the average prices appearing periodically in Publishers' Weekly, The Bookseller (London) and in the Börsenblatt für den deutschen Buchhandel (Frankfurt). There would, however, appear to be a need for a standard developed on the basis of American library acquisitions practice according to a defined statistical pattern, and which would report book and periodical price changes for the book pro- duction of the United States and certain of the major foreign ones.

A standard for accurately measuring book and periodical price changes is the more necessary in view of evidence that, while the growth of public libraries and college and university libraries during recent years has been a rather vigorous one, the portion of the total budget devoted to the purchase of books and periodicals has actually suffered a decline. ${ }^{1}$ The portion of the budget allocated to books and periodicals in public libraries, for example, has declined from $18 \%$ in 1939 , to $16.9 \%$ in $1945,15.9 \%$ in 1950 and $12.8 \%$ in $1954 .^{2}$ In college and university libraries the percentages are 36.3 for $1939-40,30.8$ for $1946-47$, and 27.54 for $195 \mathrm{I}-52 .^{3}$ This decline is of course partly attributable to increase in salaries, yet the fact remains that the portion of the budget allocated to books and periodicals has actually diminished in the face of substantial increases in book and periodical prices.

A standard of measurement for book and

${ }^{1} \mathrm{R}$. W. Frase, Economic Trends in Trade Book Publishing, in Books and the Mass Market (Urbana: Publishing, in Books and the Mass Market (Ur
University of Illinois Press, 1953), pp. 39-40.

University of Illinois Press, I953), pp. 39-40.
U. Office of Education. Public Library Statistics. Bulletin 1953, No. 9 (Washington, D.C.: Government Printing Office, I954), p. I4. (The figures for 1939-1950 reflect public libraries of all population

groups.) Circular No. 442, April, I955. (The figure for I 55 is derived from this Circular and comprises public libraries in cities of population groups of 50,000 and more.)

${ }^{3}$.) Biennial Survey of Education in the United States, 1938-1940, College and University Library Statistics I939.40 (Washington, D.C.: Government Printing Office, 1943), p. 22. (The figure of 36.3 includes binding in addition to books and periodicals.) 1946-48. Chapter 6. Statistics of Libraries in States, 1946-48. Chapter 6. Statistics of Libraries in Institu-
tions of Higher Education, 1946-47 (Washington, D.C. tions of Higher Education, 1946-47 (Washington, D.C.: Government Printing Office, I949), p. 9 .

Biennial Survey of Education in the United States, tions of Higher Education, IO5I-52 (Washington, D.C. Government Printing Office, I954), p. 27. 
periodical prices could be developed from list prices for various key years in terms of a selected base year. It is proposed to develop such average prices by subject categories using 1939 as a base period. The average prices found to have prevailed in I939 would be assigned the value of 100 and the average prices of subsequent years would be expressed in terms of this base value of 100 (e.g., if the average price for all subject categories in 1947 were $35 \%$ higher than in 1939, the increase would be expressed as an index number of 135 ).

It is intended that such a cost of books index and a companion cost of periodicals index be prepared along broad lines to insure their maximum usefulness to libraries generally. Once the standards and criteria for such indexes have been resolved, it is hoped that the actual compilation of a cost of books index and a cost of periodicals index can be done cooperatively by libraries to provide a common administrative aid.

There are important advantages in the cooperative establishment of a single system of price indexes which many, or all, American libraries could use. The indexes thereby would possess considerable statistical authority and stature; in this respect the index figures, as a single standard, could supersede the separately prepared price studies (which by their very number and often conflicting conclusions have raised doubts in the minds of administrative officials and appropriations committees about actual price changes).

The salient factors involved in the preparation of a price index are set forth below. While there would be difficulties inherent in the methods utilized to establish them, the indexes are capable of being developed to a point of great usefulness to libraries.

\section{The Cost of Books Index}

An arrangement according to broad subject division would be followed for the cost of books index. Translations, separates, textbooks, children's literature, ${ }^{4}$ reprints, almanacs, calendars, extracts, official government documents, serial publications of societies, maps, music scores would be excluded either because they do not fall within a regular acquisitions program, or simply for the purpose of limiting the inquiry. The source material for the indexes would be the list prices of the titles appearing in the various national bibliographies. Average prices would be yielded for various subject divisions.

In order to permit fairly rapid classification in the compilation of the index the subject divisions ought to be relatively few and readily applicable entities. In addition, the subject divisions should constitute meaningful and usable entities for library acquisitions planning.

The following are tentatively designated as subject divisions, permitting later consolidation if found desirable:

(a) Philosophy and religion

(b) Fine Arts

(c) Social sciences (including anthropology, economics, education, political science, psychology, history, sociology, and geography)

(d) Literature (including drama, folklore, linguistics, poetry and biography)

(e) Novels

(f) Natural sciences and technology

(g) Law

(h) Medicine

(i) Agriculture

The inclusion of a separate index to cover the novel is experimental and for the purpose of determining how closely its average price will correlate with the index as a whole.

The period to be covered by the indexes would be the calendar years 1939, 1947, I950, and 1954. The year 1939 is tentatively chosen as a base year - a period neither

4 Dependent upon support from interested educational institutions, it is proposed to include two additional categories for the U. S. portion of the cost of books index: children's literature and textbooks; the latter might be subdivided into elementary school textbooks, high school textbooks, and college textbooks. 
predominantly one of high nor of very low business activity. The year 1947 is selected as a post-war year, and 1950 is designated to establish the prices prevailing at the time of the Korean war. Compilation on an annual basis would follow after 1954 .

The countries whose book productions would have indexes prepared are: Austria, Belgium, Brazil, Denmark, France, Italy, Japan, Netherlands, Norway, Spain, Sweden, Switzerland, United Kingdom, United States, and the German Federal Republic.

It will be necessary to define "book" with respect to the question of page length, since it is on this basis that the initial selection or rejection will be made in the development of the material for the cost of books index.

Definitions of what constitutes a book vary from country to country; however, an attempt at standardization is made by UNESCO in its survey of book production: "The following definition of a book may be found appropriate for reconciling
Denmark) use the standard of IOO pages. Experimental work on the factors involved in the use of a 50-page standard, as opposed to one of 100 pages, is necessary. The use of a Ioo-page standard would be more advantageous, however, since fewer items would be involved in the compilation and tabulation.

The book index would be based on the inclusion of all eligible titles (excluding official government documents, translations, etc.) and essentially it would develop-on the basis of the definitions formulated-a concept of "average book" with its attendant average price for the various national book productions for the years designated.

An experimental index was prepared for the Swiss book production of 1939 and 1950, based on the national bibliography. ${ }^{6}$ All books of at least IOo pages were recorded on cards, in accordance with the definitions previously summarized. This resulted in the following tabulation:

\begin{tabular}{|c|c|c|c|c|c|c|c|}
\hline \multirow[b]{2}{*}{ Subject Division } & \multicolumn{2}{|c|}{ I 939} & \multirow{2}{*}{$\begin{array}{l}\text { Index } \\
\text { number }\end{array}$} & \multicolumn{2}{|c|}{1950} & \multirow{2}{*}{$\begin{array}{c}\% \\
\text { Difference }\end{array}$} & \multirow{2}{*}{$\begin{array}{c}\text { Index } \\
\text { number }\end{array}$} \\
\hline & $\begin{array}{l}\text { No. of } \\
\text { items }\end{array}$ & $\begin{array}{l}\text { Aver. } \\
\text { Price }\end{array}$ & & $\begin{array}{l}\text { No. of } \\
\text { items }\end{array}$ & $\begin{array}{l}\text { Aver. } \\
\text { Price }\end{array}$ & & \\
\hline $\begin{array}{l}\text { Philosophy and Religion } \\
\text { Fine Arts } \\
\text { Social Sciences } \\
\text { Literature } \\
\text { Novels } \\
\text { Natural Science } \\
\text { Law } \\
\text { Medicine } \\
\text { Agriculture }\end{array}$ & $\begin{array}{r}81 \\
32 \\
166 \\
153 \\
53 \\
23 \\
68 \\
29 \\
12\end{array}$ & $\begin{array}{r}6.78 \\
\text { I } 3.17 \\
7.24 \\
5.01 \\
6.27 \\
9.39 \\
8.95 \\
\text { I } 1.74 \\
5.97\end{array}$ & $\begin{array}{l}100 \\
100 \\
100 \\
100 \\
100 \\
100 \\
100 \\
100 \\
100\end{array}$ & $\begin{array}{r}181 \\
53 \\
289 \\
199 \\
165 \\
82 \\
82 \\
36 \\
13\end{array}$ & $\begin{array}{r}10.26 \\
18.80 \\
12.33 \\
11.98 \\
9.35 \\
21.65 \\
15.19 \\
13.76 \\
10.57\end{array}$ & $\begin{array}{l}+\quad 51 \\
+\quad 72 \\
+\quad 40 \\
+139 \\
+\quad 49 \\
+130 \\
+\quad 69 \\
+\quad 17 \\
+\quad 77\end{array}$ & $\begin{array}{l}151 \\
142 \\
170 \\
239 \\
149 \\
230 \\
169 \\
117 \\
177\end{array}$ \\
\hline Totals & 617 & $7 \cdot 32$ & 100 & $\mathrm{I}, \mathrm{IOO}$ & 12.73 & +73 & 173 \\
\hline
\end{tabular}

the wide variety of national definitions and fitting the aim of book production statistics: a book is a non-periodical literary publication containing 49 or more pages, not counting the covers." 5

In the UNESCO study mentioned, four countries (Italy, Sweden, Switzerland,

- UNESCO Statistical Report on Book Production, I937-I950 (Paris: UNESCO, 1952), p. 6.
The 6I "eligible" items in the 1939 Swiss bibliography represent $34 \%$ of the official book production figures $(\mathrm{I}, 8 \mathrm{O} 2)$ for that year. ${ }^{7}$ To secure a rough approximation of the number of eligible items in the various national book productions for the years to

${ }^{6}$ Covering all 12 monthly issues of the Bibliographisches Bulletin der Schweiz for 1939 , and all 24 semi-monthly issues of Das Schweizer Buch for 1950 . ${ }^{7} \mathrm{UNESCO}$, op. cit. p. 62 . 
Book production in fifteen countries, $1939^{-1} 954^{1}$

\begin{tabular}{|c|c|c|c|c|c|c|c|c|c|}
\hline \multirow[b]{2}{*}{ Country } & \multicolumn{2}{|c|}{ I939 } & \multicolumn{2}{|c|}{ I 947} & \multicolumn{2}{|c|}{1950} & \multicolumn{2}{|c|}{ I954 } & \multirow{2}{*}{$\begin{array}{l}\text { Total } \\
\text { Eligibles } \\
4 \text { years }\end{array}$} \\
\hline & Total & $\begin{array}{l}\text { Est. } \\
\text { Elig. }\end{array}$ & Total & $\begin{array}{l}\text { Est. } \\
\text { Elig. }\end{array}$ & Total & $\begin{array}{l}\text { Est. } \\
\text { Elig. }\end{array}$ & Total & $\begin{array}{l}\text { Est. } \\
\text { Elig. }\end{array}$ & \\
\hline $\begin{array}{l}\text { United States } \\
\text { United Kingdom } \\
\text { Germany }^{2} \\
\text { France }^{3} \\
\text { Japan } \\
\text { Italy } \\
\text { Netherlands } \\
\text { Austria }^{6} \\
\text { Belgium }^{7} \\
\text { Sweden }^{8} \\
\text { Switzerland } \\
\text { Norway } \\
\text { Brazili0 } \\
\text { Spain }^{11} \\
\text { Denmark }\end{array}$ & $\begin{array}{r}10,640 \\
14,904 \\
20,378 \\
8,124 \\
26,435 \\
10,465 \\
6,554 \\
1,489 \\
3,624 \\
2,954 \\
1,802 \\
2,458 \\
2,000 \\
2,587 \\
3,423\end{array}$ & $\begin{array}{r}4,256 \\
5,962 \\
8,152 \\
3,250 \\
10,574 \\
4,186 \\
2,621 \\
596 \\
1,450 \\
1,181 \\
721 \\
984 \\
800 \\
1,032 \\
1,370\end{array}$ & $\begin{array}{r}9, \text { I } 82 \\
13,046 \\
8,6 \text { I } 2 \\
13,4 \text { I } 9 \\
6,175 \\
5,770 \\
7,086 \\
2,891 \\
3,000 \\
3,453 \\
3,810 \\
2,585 \\
2,000 \\
3,643 \\
3,353\end{array}$ & $\begin{array}{r}3,673 \\
5,219 \\
3,445 \\
5,368 \\
2,470 \\
2,308 \\
2,835 \\
1,157 \\
1,200 \\
1,382 \\
1,524 \\
1,034 \\
800 \\
\text { I , 458 } \\
\text { I } 342\end{array}$ & $\begin{array}{r}11,022 \\
17,072 \\
14,094 \\
9,993 \\
13,009 \\
8,904 \\
6,537 \\
3,788 \\
4,574 \\
3,506 \\
3,527 \\
2,548 \\
2,000 \\
3,633 \\
3,508\end{array}$ & $\begin{array}{r}4,409 \\
6,829 \\
5,638 \\
3,998 \\
5,204 \\
3,562 \\
2,615 \\
1,516 \\
1,831 \\
1,403 \\
I, 411 \\
1,020 \\
800 \\
I, 454 \\
I, 404\end{array}$ & $\begin{array}{r}11, \infty 00 \\
18, \infty 00 \\
15, \infty 00 \\
10,000 \\
15, \infty \infty \\
9, \infty 00 \\
7,000 \\
4, \infty 00 \\
4, \infty 00 \\
4, \infty 00 \\
4, \infty \infty \\
3,000 \\
2,000 \\
3,600 \\
3,600\end{array}$ & $\begin{array}{r}4,400 \\
7,200 \\
6,000 \\
4,000 \\
6,000 \\
3,600 \\
2,800 \\
1,600 \\
1,600 \\
1,600 \\
1,600 \\
1,200 \\
1,800 \\
1,440 \\
1,440\end{array}$ & $\begin{array}{r}16,738 \\
25,210 \\
23,235 \\
16,616 \\
24,248 \\
13,656 \\
10,871 \\
4,869 \\
6,081 \\
5,566 \\
5,526 \\
4,238 \\
3,200 \\
5,384 \\
5,556\end{array}$ \\
\hline & I I 7,837 & 47,135 & 88,025 & 35,2 I 5 & 107,7 I 5 & 43,094 & I I 3,200 & 45,280 & 170,724 \\
\hline
\end{tabular}

1 Except where otherwise noted, the source for these figures is UNESCO Statistical Report on Book Production, 1937-1950 (Paris: Unesco, 1952). The figures fuction, $1937-1950$ (Paris: for 1954 are

preceding years. The post-i 939 figures are for the German Federal Republic only. The figure listed for 1950 is actually for $195 \mathrm{I}$ and is derived from Sigfried Taubert, Grundriss des Buchhandels in aller Welt (Hamburg: E. Hauswedell, 1953), D. 88.

3 France. Figure under 1939 actually that for 1938 .

4 Japan. Shuppan nenkan (Publications Yearbook) for I940 and I95I; Nihen shuppan nenkan. (Japan for I 940 and I95I; Nihen shuppan
Publications Yearbook) for 1947-48.

be surveyed, an even $40 \%$ was used in preparation of the following summary.

The development of the data for a cost of books index, and their later tabulation, could be conveniently accomplished through the use of punched cards. On the experimental punched card illustrated, the left hand portion would be checked by the person examining the bibliography (the "reader") for the eligible items, and the right hand portion would be used for punching the data recorded on the left. The year and country would be gang-punched. The reader would check-mark the proper subject division, either the bound or unbound box, record the number of pages, and the price in the national currency. (The issue number of the bibliography, and either the item number or page number would also be recorded.) The box labeled "question"
S Netherlands. Figure for 1950 from Taubert, op. cit., p. ${ }_{6}^{202}$.

Austria. Figure under 1939 actually that for 1937 7 Belgium. Figure under I 939 actually that for 1934 , from Taubert, op. cit.

${ }^{8}$ Sweden. Figure for 1950 from Taubert, op. cit., p. 254 .

9 Norway. Figure for 1950 from Taubert, op. cit.

p. ${ }_{10}^{212}$ Brazil. Estimated figures supplied by Hispanic Foundation, Library of Congress.

11 Spain. Figure under 1939 actually that for 1940. 12 Denmark. Figure under I 939 actually that for 1940.

would be check-marked if the reader were doubtful of an item's inclusion; the question cards would be sorted out and examined by a reviser. To secure the average prices, the cards would be totaled on the tabulator in the national currency, converted to U.S. currency at the rate of exchange prevailing during the particular year, or the average rate of exchange for that year, and then averaged. The utilization of punched cards will facilitate the central tabulation of data developed at several different locations.

\section{A Cost of Periodicals Index}

A cost of periodicals index would be developed for the same countries as would the cost of books index; the base period, reporting years, and the subject divisions (excepting novels) would likewise be identical.

The index reflecting changes in the cost 


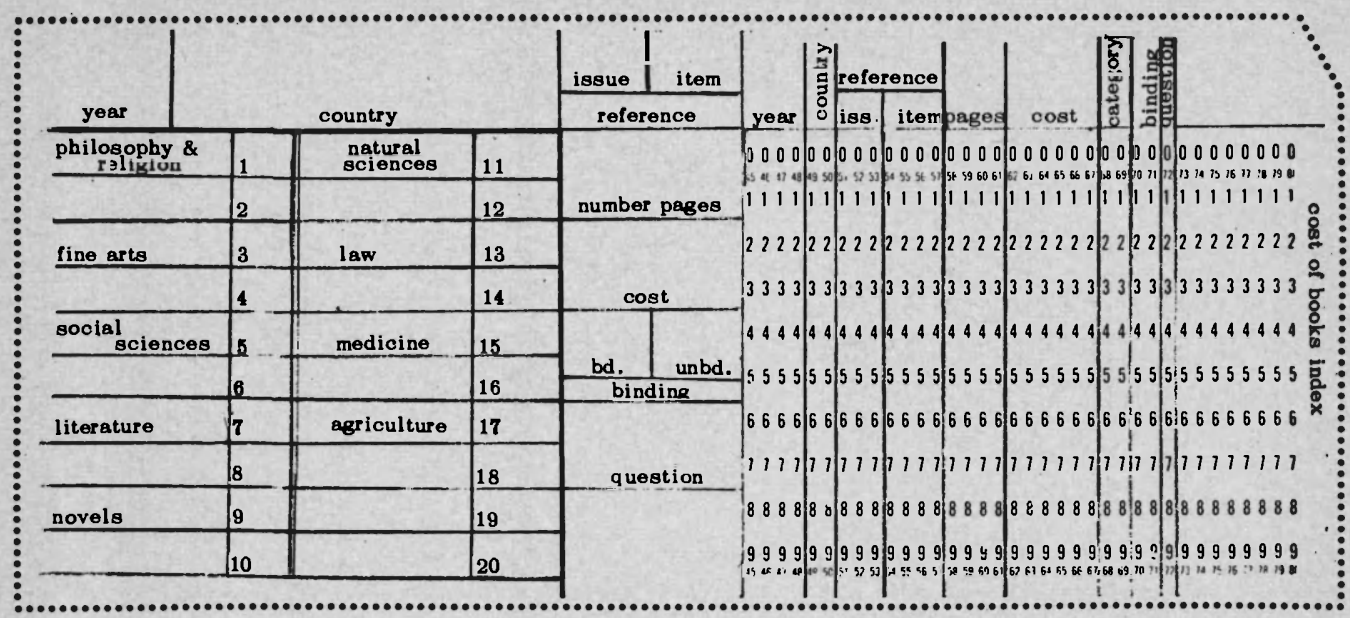

Sample of Punched Card

of periodicals would differ in its derivation from the index for books. Basically the same periodicals would be utilized for the entire period 1939-1954, their prices ascertained, averaged, and then converted into index numbers based on the 1939 prices. Thus the periodicals index would make use of the factor of continuity of publication, in contrast to the development of a cost of books index.

The construction of the index would be based on the number of periodicals published in a particular country and their numerical distribution within the subject divisions, that is, the total number of periodicals constituting the index itself would be determined by the total number of periodicals published in a particular country. This would be accomplished through a sampling procedure.

Although the basic core of the index would consist of the same titles beginning with the base period of 1939 it will be desirable to add newly issued titles for the years of reporting (1947, 1950, etc.). The inclusion of new titles with nascent editorial and manufacturing costs would make the index more representative of the publishing scene. In addition to this economic factor, certain of the new titles would reflect new fields of interest and techniques within the subject divisions (e.g., journals in the field of gerontology and antibiotics might be included in the index for Medicine), thereby making for adequate representation within the subject.

The change in the composition and quality of the individual periodical during the period 1939-1954 merits attention. The use of the same periodical titles in the index in a sense implies the measurement of the same substance throughout this period. Thus the question of comparative value is raised rather forcibly at intervals during this period since a pattern for the comparison conveniently exists-the individual publisher's original editorial practice in format, use of illustrations, quality of paper, etc. In developing a cost of books index the aspect of comparison does not arise as sharply because of the dissimilarities among books and the averages in the cost of books index would reflect the quality of paper, binding, and general characteristic prevalent during a particular year. Similarly, the main consideration in a cost of periodicals index would be that it constitute a measurement of the periodicals being published. 
Natural and Applied Sciences

\begin{tabular}{|c|c|c|c|c|c|}
\hline & I939 & I947 & I 950 & I954 & I955 \\
\hline $\begin{array}{l}\text { American Assoc. of Petroleum Geologists Bulletin } \\
\text { (Tulsa, Okla.) } \\
\text { American Fournal of Mathematics (Baltimore) } \\
\text { American Fournal of Science (New Haven) } \\
\text { American Railway Engineering Assoc. (Chicago) } \\
\text { Diesel Progress (Los Angeles) } \\
\text { Ecology (Brooklyn and Durham) } \\
\text { Electrical World (New York) } \\
\text { Engineering and Mining Fournal (New York) } \\
\text { Entomological News (Phila.) } \\
\text { Franklin Institute Fournal (Phila.) } \\
\text { Fournal of Applied Physics (New York) } \\
\text { Fournal of Chemical Physics (New York) } \\
\text { Fournal of Geology (Chicago) } \\
\text { Fournal of Organic Chemistry (Baltimore) } \\
\text { Fournal of Paleontology (Tulsa, Okla.) } \\
\text { Mechanical Engineering (New York) } \\
\text { Physiological Zoology (Chicago) }\end{array}$ & $\begin{array}{r}10.00 \\
7.50 \\
6.00 \\
10.00 \\
3.00 \\
5.00 \\
4.00 \\
3.00 \\
3.00 \\
6.00 \\
7.00 \\
10.00 \\
6.00 \\
6.00 \\
6.00 \\
5.00 \\
7.50\end{array}$ & $\begin{array}{r}15.00 \\
7.50 \\
6.00 \\
10.00 \\
5.00 \\
5.00 \\
6.00 \\
3.00 \\
3.00 \\
6.00 \\
7.00 \\
10.00 \\
6.00 \\
6.00 \\
6.00 \\
6.00 \\
10.00\end{array}$ & $\begin{array}{r}15.00 \\
7.50 \\
8.00 \\
10.00 \\
5.00 \\
7.50 \\
6.00 \\
3.00 \\
3.00 \\
8.00 \\
9.00 \\
15.00 \\
6.00 \\
6.00 \\
6.00 \\
7.00 \\
10.00\end{array}$ & $\begin{array}{r}18.00 \\
8.50 \\
8.00 \\
10.00 \\
5.00 \\
7.50 \\
6.00 \\
3.00 \\
5.00 \\
10.00 \\
12.00 \\
15.00 \\
7.00 \\
14.00 \\
10.00 \\
7.00 \\
10.00\end{array}$ & $\begin{array}{r}18.00 \\
8.50 \\
10.00 \\
10.00 \\
5.00 \\
7.50 \\
6.00 \\
3.00 \\
5.00 \\
10.00 \\
12.00 \\
15.00 \\
7.00 \\
14.00 \\
10.00 \\
7.00 \\
10.00\end{array}$ \\
\hline Totals & 105.00 & $123 \cdot 50$ & 132.00 & I 56.00 & 158.00 \\
\hline Index for Natural and Applied Sciences & 100.0 & I 77.6 & $125 \cdot 7$ & $148 \cdot 5$ & 150.4 \\
\hline
\end{tabular}

Merely for purposes of illustrating a pattern, prices have been developed for the following group of American periodicals selected at random for the subject division of natural and applied sciences (including technology). In practice, prices would be recorded annually on a master list of the titles comprising all the subject divisions of the index. Annually only the index number for each subject division, as well as the index number for the aggregate of all titles forming the index, could be published.

Since the development of price indexes would be a matter of practical interest to library administrators, comments and suggestions would be gratefully received by the writer. Further experimental work is being continued, and the subject of price indexes will constitute the topic of a thesis for the degree of M.S. in L.S. at the Catholic University of America.

The Board on Acquisition of Library Materials (American Library Association) has expressed an interest in the development of the indexes. Its chairman, Mr. Robert Vosper, has made known to the director of the thesis, the Reverend James J. Kortendick, head of the Department of Library Science at the Catholic University, the Board's willingness to offer such advice and counsel, through Mr. Edwin E. Williams, chief of the Acquisitions Department at the Harvard University Library, and Mr. Melvin J. Voigt, assistant librarian at the University of California Library at Berkeley, as may be appropriate in the development of the price indexes. 